\title{
Morphology and Properties of Mo Doped Monodispersed Titania Particles
}

\author{
Václav Šteng1*, Nataliya Murafa*, Snejana Bakardjieva* \\ *Institute of Inorganic Chemistry of the ASCR, v. v. i., 25068 Řež, Czech Republic
}

Titanium dioxide is one of the most efficient photocatalysts for the detoxifcation of organically charged waste water. However, this material suffers from the drawback of poor absorption properties because of a band gap of $3.2 \mathrm{eV}$. Thus, wavelengths shorter than $400 \mathrm{~nm}$ are needed for light induced generation of $\mathrm{e}^{-} / \mathrm{h}^{+}$pairs. Therefore, doping with transition metal ions is interesting for inducing a red-shift of the band gap. However, this doping changes other physical properties such as lifetime of $\mathrm{e}^{-} / \mathrm{h}^{+}$pairs and adsorption characteristics. This paper deals with doping titania by $\mathrm{Mo}^{6+}$ ions. Photocatalysis of trichloroethylene with $\mathrm{TiO}_{2}$ and molybdenum-doped $\mathrm{TiO}_{2}$ mixed oxide was studied in this work [1] using a tubular quartz reactor packed with photocatalyst-coated glass beads. Nano-sized molybdenum-doped $\mathrm{TiO}_{2}$ mixed oxide photocatalysts were prepared with the $\mathrm{Mo}^{5+}$ content varying from 0 up to $2.5 \mathrm{~mol} \%$, to shift the absorption onset into the visible region and to enhance the efficiency of photocatalytic activity by retarding the $\mathrm{e}^{-} / \mathrm{h}^{+}$recombination [2]. In a typical experiment, titanyl oxo-sulphate was dissolved in $100 \mathrm{ml}$ of distilled water $(1.6 \mathrm{M})$ and hydrolyzed by slow addition of ammonium hydroxide solution (10\%) under constant stirring at temperature of $0{ }^{\circ} \mathrm{C}$ in ice bath, until the reaction mixture reaches $\mathrm{pH} \mathrm{8.0.} \mathrm{The} \mathrm{obtained} \mathrm{white}$ precipitate was separated by filtration and was washed free of sulphate ions (confirmed by the $\mathrm{BaCl}_{2}$ test) with distilled water. Obtained wet precipitate was mixed with $100 \mathrm{ml}$ of $30 \% \mathrm{H}_{2} \mathrm{O}_{2}$ solution and yellow gelatinous mass was obtained. The yellow see-through gelatin product obtained by foregoing reaction was mixed with defined amount of ammonium heptamolybdate tetrahydrate $\left(\mathrm{NH}_{4}\right)_{6} \mathrm{Mo}_{7} \mathrm{O}_{24} \bullet 4 \mathrm{H}_{2} \mathrm{O}$ diluted with $10 \mathrm{ml} \mathrm{H} \mathrm{O}_{2}$ (Tab. 1.) and subsequently heated in heating mantle in round-bottom flask with a reflux cooler. During the heating process white precipitate originated. Annealing had been continued till the precipitate changed its color to white or slightly blue $(\sim 36$ hours). The obtained precipitate was dried in the oven at $105^{\circ} \mathrm{C}$. HRTEM images of $\mathrm{Mo}^{6+}$ doped anatase particles are shown in Fig 1. The aspect ratio of anatase particle decreased gradually with the addition of molybdenum, and changes the morphology of particles from spindle-like shapes to the shape of rectangular or square cross-section. The HRTEM image confirms that the particles are of anatase structure with the c-axis of the tetragonal crystal collinear with the long axis of the spindle, as indicated by the crystal planes. The fine fringe spacing $d$ along the [101] direction of the anatase crystal linearly increased with the amount of doping agent. These images clearly show that this is a very good crystalline material, which contains no amorphous domains. The absence of these amorphous domains is an essential prerequisite for good photocatalytic properties.

\section{References:}

[1] J. K. Yoon, W. S.Yoon et al., J. of the Korean Inst. of Chem. Engineer, 38 (2000) 288-295

[2] M. S. Jeon, W. S. Yoon, H. Joo, T. K. Lee, H. Lee, Applied Surface Science 165 (2000) 209-216

[3] This work was supported by the Academy of Sciences of the Czech Republic (AV OZ 40320502) 
Tab. 1. Characteristics of prepared titania samples doped by variable amounts of Mo

\begin{tabular}{|c|c|c|c|c|c|c|c|}
\hline Sample & $\begin{array}{c}\left(\mathrm{NH}_{4}\right)_{6} \mathrm{Mo}_{7} \mathrm{~N}_{24} \\
\cdot 4 \mathrm{H}_{2} \mathrm{O} \\
{[\mathrm{g}]}\end{array}$ & $\begin{array}{c}\text { Crystallite } \\
\text { size } \\
{[\mathrm{nm}]}\end{array}$ & $\begin{array}{l}\text { Aspect } \\
\text { ratio } \\
\text { l/d }\end{array}$ & $\underset{\left[\mathrm{m}^{2} \mathbf{g}^{-1}\right]}{\text { BET }}$ & $\begin{array}{c}\text { Total } \\
\text { pore } \\
\text { volume } \\
{\left[\mathrm{cm}^{3} \mathbf{g}^{-1}\right]}\end{array}$ & $\begin{array}{c}\text { Cell } \\
\text { param. } \\
\text { a } \\
{[\AA \AA \AA}\end{array}$ & $\begin{array}{c}\text { Cell } \\
\text { param. } \\
\text { c } \\
{[\AA]}\end{array}$ \\
\hline TiMo_1 & 0.05 & 26.2 & 3.1 & 64.4 & 0.3645 & 3.79367 & 9.50879 \\
\hline TiMo_2 & 0.10 & 26.2 & 4.6 & 100.8 & 0.2890 & 3.79467 & 9.51107 \\
\hline TiMo_3 & 0.15 & 45.7 & 3.6 & 56.4 & 0.2925 & 3.79616 & 9.51172 \\
\hline TiMo_4 & 0.25 & 25.6 & 2.5 & 109.4 & 0.2861 & 3.79717 & 9.51300 \\
\hline TiMo_5 & 0.50 & 24.2 & 1.2 & 107.7 & 0.3024 & 3.79870 & 9.50139 \\
\hline TiMo_6 & 1.00 & 15.6 & 1.0 & 153.2 & 0.3007 & 3.79936 & 9.50775 \\
\hline
\end{tabular}

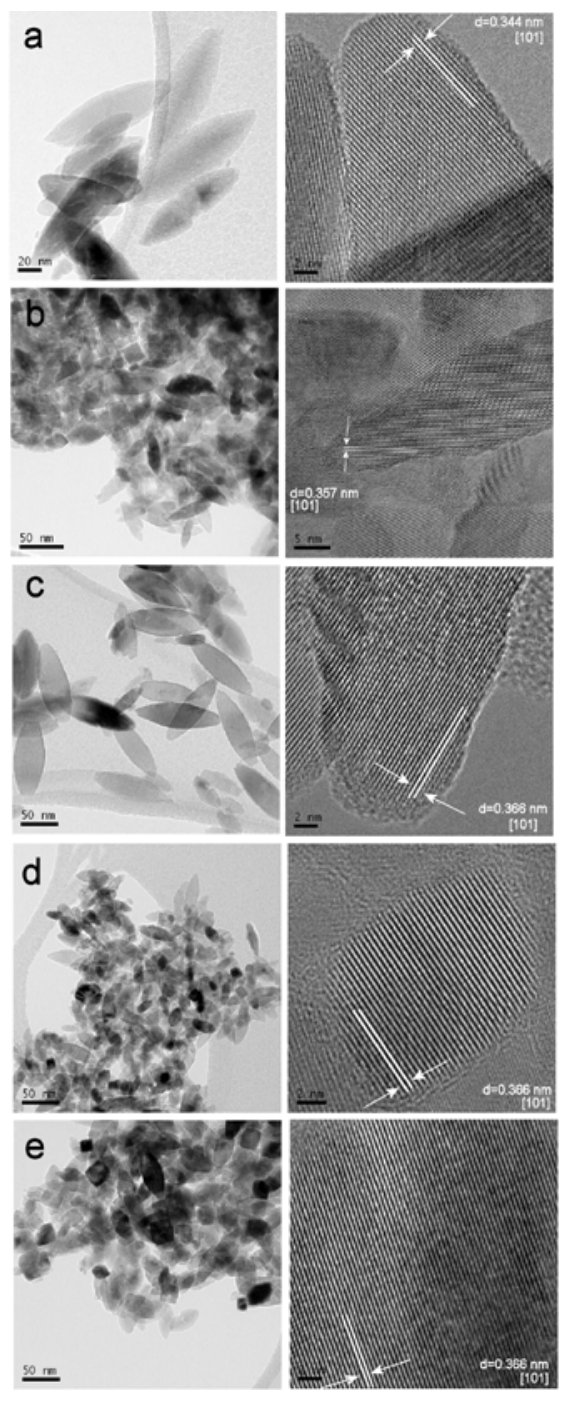

Fig. 1. Molybdenum doped monodispersed titania samples a) TiMo_1, b) TiMo_2, c) TiMo_3 d) TiMo_4 and e) TiMo_5 